\title{
THE ORAL AURALITY OF THE RADIO WARAY SIDAY
}

\author{
Maria Rocini E. Tenasas \\ Ateneo de Manila University \\ Leyte Normal University \\ ma.rocini.tenasas@lnu.edu.ph
}

\begin{abstract}
The end of print culture raises many disturbing questions about the position of poetry amidst these immense cultural and technological changes. What will be the place of the poet and his poetry in society now that we are at the cutting edge of technology? What will be the advantage of poetry in what Walter J. Ong calls the technologizing of the word?

This study focuses on how the Waray siday as vernacular poetry from the margins emerges into a new form of oral history, known now as secondary orality, as it finds its way on the radio. It analyzes the distinct oral and aural qualities of the radio Waray siday as oral poetry, and how this soundscape somehow contributed to the characteristics of Waray language as reflected in the radio Waray siday. It illustrates how the interplay of orality and aurality create sense and affect in the radio Waray siday that makes it a revitalized, modernized, and powerful poetry. Analysis is grounded on the affect theory which posits that the affective power of the voice (orality), combined with the intimacy of the listening process (aurality), results in a change in behavior realized by listening to the reading of oral poetry; the orality theory which contends the intrinsic superiority of oral to written poetry, even in the age of print; and the radio inclusive theory which shows the link between the radio text, context, and reception. It describes the hybridity of the radio and its intertextuality-an exploration into a multidimensional phenomenon. This paper emphasizes that the meaning of poetry exists in relation to sound (letters waiting to become sound) and visual shape-that sound/shape articulates (and creates) meaning transcribed by a writing that "listens" to reading. ${ }^{1}$
\end{abstract}

\section{Keywords}

radio poetry, regional folk poetry, secondary orality, soundscape, sound culture, vernacular poetry 


\section{About the Author}

Maria Rocini E. Tenasas is an associate professor of the Languages and Literature Unit of Leyte Normal University in Eastern Visayas. She holds a Master of Arts degree in Educational Administration from Macquarie University in Sydney, Australia, and a Master of Arts in English Language and Literature Teaching from the Ateneo de Manila University where she is also a candidate for Doctor of Philosophy in English Language and Literature. She has also presented in local and international research conferences. Her research interests include regional literature, interdisciplinary studies, aurality, soundscapes, corpus-based analysis on the language of disaster, translanguaging in language and education, and language assessment and evaluation.

Kritika Kultura 35 (2020): 119-153

(c) Ateneo de Manila University

<http://journals.ateneo.edu/ojs/kk/> 
The dawn of the Digital Age has given birth to a massive cultural revolution in the whole of humanity. Since the proliferation of electronic technology, print has lost its supremacy in communication. Dana Gioia in "Disappearing Ink: Poetry at the End of Print Culture" shows a survey conducted in the US as early as 1999, which mentions that even just a child mostly spends 5 hours and 48 minutes each day with electronic media, while only 44 minutes with print (22). For scholars, the implications of the shift from print culture to electronic media are massive, complicated, and often disturbing. Although, indeed, books, magazines, and newspapers are not vanishing, their prominence in the culture has changed considerably over the past few decades, even among the educated. Presently, we are confronted with a generation of young intellectuals who are not opposed to reading, yet, they are uninterested in immersing themselves in the world of books. These new media have gradually changed not only the way we sense language and ideas but also the world and ourselves. Likewise, literature, especially oral poetry, in particular, and poetry, in general, have been profoundly affected in many ways that we are still in the process of comprehending.

Before the days of writing, the sense of hearing was more vital than the sense of sight. The aural sense tends to predominate. Walter J. Ong in his work Orality and Literacy: The Technologizing of the Word posits that "electronic transformation of verbal expression has both deepened the commitment of the word to space initiated by writing and intensified by print and has brought consciousness to a new age of secondary orality" (135). Likewise, this explains also how telephone, cellular phones, radio, television, and various kinds of sound tape, or electronic technology, have brought us into the age of "secondary orality." According to Ong, "the new medium reinforces the old, but of course transforms it because it fosters a new, self-consciously informal style" (136).

The technology used to present information is never neutral. Ong argues that "writing as technology, transforms human consciousness." He emphasizes that "humanity shapes and is shaped by technology" (35). For him, how a medium works dictates the kinds of content it communicates, or to revise Marshall McLuhan's famous formula, the medium predetermines the message. The end of print culture raises many disturbing questions about the position of poetry amidst these immense cultural and technological changes. What will be the place of the poet and his poetry in society now that we are at the cutting edge of technology? How can we perpetuate a love for poetry among the younger generation which has seen increasingly little use for books, little knowledge of the past, little regard of literary value, and even little faith in poetry itself? What will be the advantage of poetry in what Ong calls the technologizing of the word? 
Consequently, with the introduction of high technology, the siday as part of Waray oral tradition gets revitalized and modernized through a broadcast medium, the radio. Interestingly, to accommodate the new experience, the old Waray oral poetry known as "sidai" adopts a new spelling. It is now known as "siday," the Waray contemporary poetry. Technology brings the siday to a new peak which Ong describes as secondary orality. In this paper, aurality refers to the oral performance of reciting poetry as in the case of the radio Waray siday through radio broadcasting. Meanwhile, secondary orality denotes the electronic transformation of verbal expression through the intervention of electronic technology as medium of communication.

In the 1980s, a new breed of siday emerged. This is the DYVL siday, a popular radio program in the Waray region. Remarkably, the DYVL siday has been so strongly engraved in the Waray culture that once the word is mentioned, it generally means poetry, and the poetry of Leyte and Samar is now called siday (Bagulaya 87). However, unlike poetry written by trained poets, the DYVL siday is composed by the ordinary folks with no formal training.

Studying the connection between the Waray siday, oral poetry from Eastern Visayas, and the radio as technology reveals that the radio is an ideal medium for dissemination, since it has fundamentally an oral-aural quality of poetry which makes it more appealing to the audience. The Waray siday emerges into a new form of oral history, known now as secondary orality, as it finds its way on the radio. Including the history of radio poetry and how it popularized poetry in the past, in general, and the emergence and inclusion of the Waray siday in the DYVL radio, in particular enables an analysis of the distinct oral and aural qualities of the radio Waray siday as an oral poetry of Leyte: how the place or soundscape somehow contributed to the characteristics of Waray language, and how it is reflected in the radio Waray siday. Further, hermeneutic close reading and close listening of the poems illustrates that the interplay of orality and aurality creates sense and affect in the radio Waray siday, making powerful poetry. To enrich and reinforce the hermeneutic analysis of the close reading and close listening of the radio Waray siday, the researcher also included unstructured interviews with some key informants. ${ }^{2}$ Hence, the analysis incorporates some observations and reactions from the radio audience and is grounded on the following theories: affect theory which posits that the affective power of the voice (orality), combined with the intimacy of the listening process (aurality), results in a change in behavior realized by listening to the reading of oral poetry; the orality theory which contends the intrinsic superiority of oral to written poetry, even in the age of print; and the radio inclusive theory which claims that aurality is central to radio theory as it links the radio text, context, and reception. Aurality matches with film's "specularity." It refers to the listening-to-ness of the audience, the heard-of-ness of the performer 
(broadcaster), and the listening itself: the "listening that" and the "listening how" (Beck). The meaning of poetry exists in relation to sound (letters waiting to become sound) and visual shape - that sound/shape articulates (and creates) meaning transcribed by a writing that "listens" to reading (Ratcliffe 3 ).

There is another kind of audio world that is a sound-only medium like the radio which is distinctively suited for the siday. It is a world of sound which is essentially, at its heart, poetic. More so, there is something within the medium itself, which can captivate, that which cannot be expressed in prose. The voices from words coming together through the air can hold certain magic and mystery though fleeting in nature; it is a concept that is at the same time scientific and poetic. The radio I want to explore here is not a radio of journalism, but a medium in which through the partnership between the imagination of the listener and the maker of the sounds creates something which is more of poetry.

I seek to examine what poetry and sound have in common. Before there were electronic means of making and reproducing sound, poets from the beginnings of the oral tradition were evoking sound through their words. Radio in a way has wrested the oral tradition back from the printed page, and today, with a textbased website working alongside broadcast, the best of all possible worlds is at our disposal.

Everyday people speak metaphorically, particularly when they are passionate. So there is inherent poetry in the way we speak. I want to explore the poetry of the vernacular; the vernacular not only of the human speech, but in the sounds of the other humans from the margins, and the very breath and movement of the region or community itself finding its own identity.

\section{RADIO POETRY: A BRIEF HISTORICAL CONTEXT}

To give insights on radio poetry, I include in the discussion radio poetry in the US because of its most notable influence on us in radio. John Spaulding in "Poetry and the Media: The Decline of Popular Poetry" narrates that during the first half of the century in the US, poetry was not cloistered in universities nor was its publication limited to literary magazines with small publications (149). Accordingly, poetry was part of the mainstream popular culture, just as fiction today, rather than being limited to the small, elite world of poets themselves. It was in the 1930s, the new era, when radio seemed to be the ideal medium for poetry. During the 1930 and 1940s, many radio stations had their own bards who read poems sent in by contributors, clippings from newspapers, and poems by established poets. Three of the most 
popular voices were Ted Malone, David Ross, and Tony Wons, who also published their favorite selections in book form (Spaulding 149). It was also in the 1930s and 1940s when verse drama was written specifically for radio presentation. Archibald MacLeish might be called the "father of radio drama in verse," for his "The Fall of the City," the first American verse play ever written and performed on network radio in 1937, which was widely hailed as a critical and popular success (Spaulding 150). In his introduction to "The Fall of the City," MacLeish encouraged poets to write for radio: "I am anxious to persuade American poets to experiment with verse plays for radio ... The ear is the poet's perfect audience, his only true audience. And it is radio and only radio which can give him access to this perfect friend" (Spaulding 150).

The radio, indeed, should be a potent instrument for the reestablishment of delight in poetry. Education magazines agreed as well: "Radio is the technological Moses that will lead poets out of their house of bondage . . . Radio would give poetry back to the people" (qtd. in Spaulding 150).

During the 1930 s and 1940s, poets looked to radio to provide a reintegration of drama and poetry. For radio to offer this hope was paradoxical, for radio itself was the offspring of the very technology that had caused the displacement of poetry.

In the 1930s, Philippine radio replicated the development in the US (Aniceto et al. 19). According to Elizabeth L. Enriquez in Early Philippine Radio, the period from 1922 through the Japanese years until 1949 when the US granted the Philippines its independence, provides the perfect introduction to radio's "golden age" (qtd. in Aniceto et al. 28). Prewar radio in the Philippines was only good for plain entertainment which only in the later years became a source of information (Aniceto et al. 188). So Philippine radio's golden years actually began after World War II and lasted up to the early 1960s (183). The 1950s was the apex of Philippine radio's golden years despite the stealthy entry of the television.

Early Philippine radio had a distinctly American flavor, after it became a lively cultural practice (34). As recalled by Ben Aniceto, "those delicious times of the 1930s, growing up in a city with predominantly Oriental setting, but Occidental in culture, in religion, and in ineluctable prejudices (40)... These were the times when the radio was the most important piece of furniture in most houses . . . Poetry and music were the 'in' things. Women were attracted to men who knew how to recite Shakespeare, play the piano or violin, blow the saxophone or sing a la Caruso, Vallee or Crosby" (6o).

However, radio poetry in the Philippines was not so popular, unlike in the US. By the mid-1950s, however, only a few radio programs of poetry readings in the 
US remained, as the format of radio broadcasting was changing in response to the popular appeal of television.

Mass media in the US has largely abandoned poetry as a result of technology. This scenario is not far off from the Philippines. The endangerment of traditional regional literature in our country is not only experienced by the less established minority but also by powerful and institutionally worthwhile regional languages. Poetry is also somewhat neglected, if not forgotten. As Merlie Alunan commented in "Latitudes of Intimacy: New Waray Writing and National Literature," "among the Warays where tradition was never strong to begin with, the writing was almost stopped. Thus, in the 1980 os the writing had become dated, mired in tradition, irrelevant to the evolving lifestyles in the region." As highlighted by an interview of Bienvenido Lumbera, "not much is produced in some regional literatures; in fact some are moribund or dying, as in the case of Waray literature and, to some extent, in Cebuano literature" (qtd. in Alburo 66). Literature from the periphery has become more and more negligible as the passion for poetry diminishes with time.

\section{EMERGENCE OF THE RADIO WARAY SIDAY}

Like in most human societies, the Waray literature of Leyte in Eastern Visayas started as an oral tradition of what Ong calls "primary orality," that is, far from the influence of print culture. According to Francisco Ignacio Alzina, a Spanish Jesuit, "Waray Literature is predominantly poetry which took shape in the early seventeenth century" (Luangco 6o). It dates back to the pre-Hispanic period when it was mainly oral. The sidai (old spelling) is among the oldest recorded Waray poetry. It is an oral poetic form considered to be the most difficult of all to compose because the meter is irregular and the language is highly metaphorical. It contains constant repetitions of very long phrases, which the townsfolk sometimes find boring. The early sidai was sung. Its purpose was to praise people, to relate the accomplishments of ancestors, and to express of the beauty of women.

Among the earliest Waray poetry, it was only the sidai (now siday) that has evolved from an oral form to a written form. According to Ma. Luz C. Vilches on "A Preliminary Survey of Waray Poetry", "it has retained its serious intent: always reflective and almost always occasional" (19). She further explains that the sidai became so popular among the Waray writers perhaps because of the adaptability of its form to different themes for different occasions (62). However, with the introduction of high technology, the sidai as part of Waray oral tradition finds a niche in media, specifically the radio. 
In the Philippines, the transistor radio is an innovation which is a revolutionary determinant of Philippine society predominantly on the local level. Barrio folks, usually remote from the outside world, are able to engage in fresh ideas and keep abreast of both national and international developments through the radio. Consequently, the transistor radio somehow replaced the usual practice of getting information through word of mouth. The transistor revolution in the Philippines began in 1959 when Cooperative American Relief Everywhere (CARE), a cooperative of American private charitable and service organizations, donated a few thousand transistors to the barrios (Lent 37).

Looking back at the history of the radio in the Philippines, Enriquez pointed out that "commercial broadcasting developed rapidly after the war and that more radio sets were found in the provinces than before as rural folk." Further, she stated that "the size of the audience grew as the radio set occupied a central position, both literally and figuratively, like that of a throne in the homes of Filipinos" (Enriquez 165). Radio is more than just a media channel to many Filipinos, it is a way of life. It is part of Filipino culture (Tuazon 1). According to Enriquez, "broadcasting in the Philippines became a cultural expression," and that it brought about an impact to the consciousness and sense of identity of Filipinos. Further, she said that "the Filipinos appropriated this alien cultural practice, took it as their own, used it, explored it, and converted it for their own purposes" (5). Accordingly, "Philippine radio after the World War II was not only the chief entertainer of the Filipino people but also the principal storyteller, defender, and articulator of sentiments" (Enriquez 184).

Furthermore, Lent in his paper "Philippine Radio: History and Problems" mentions that "the transistor becomes a supplement to the word-of-mouth source of news, more so the villagers are openly accepting its soap operas, balagtasan (debates in verse), advice-to-the-lovelorn programs and music fare" (37). Hence, besides its entertaining function and social function, the transistor became a status symbol as well. Moreso, "the postwar radio has a unifying effect to the Filipino people having used and taught them the national language, Tagalog. The rural folks love the radio station that speaks the language of the people, and that tells stories about the ordinary folks in soap operas-from the jilted sweetheart, to the uncaring lover, and the long suffering mother which reaffirm their values as a people" (49).

Undoubtedly, technology brings the Waray siday (new spelling) to a new peak which Ong describes as secondary orality. It was in the 1980 os when a new breed of siday emerged. The DYVL siday became popular among the Waray through the mass medium radio. DYVL, the Voice of Leyte and Samar where the popular radio siday was aired, was the oldest radio station in Region VIII. It started its commercial broadcast on October 17, 1956. It was as well the first radio station in Region VIII to produce programs in Waray, the language of the people of Eastern Visayas. 
The DYVL siday was a long-running program of DYVL. According to one of its oldest employees, it started as a brilliant thought in 1979 to add an attraction to the morning news via ending it with an appropriate quotation of the day in Waray; this continued for a whole year (Alunan et al. 2). The next year, in 1980, the notion of the daily quotation was expanded by inviting listeners to send their own sayings and quotations to be read on air, to which the audience response was instantaneous and enthusiastic. Consequently, the excited listeners contributed submission of not only two or three lines, but rather whole stanzas which could be considered whole poems. Eventually, DYVL decided to detach the quotation portion from the morning news and gave it its own airspace. It was dubbed at first as Puplonganon (2). Puplonganun literally means "saying" or "quotation," or "proverb." It refers to an expression distinguished by elegance, grace, wit, or aptness (Alunan et al. 2). As characterized in the early folk poetry of Leyte, didacticism can be seen as a motivating factor in most of their poetry. In fact, early poets in Leyte seriously thought of a poem with a "moral philosophy" as still the best (Vilches 40).

Because of the continuous number of contributions written in stanzas, they made Puplonganun a regular feature and called it siday. The Puplonganun or siday (which means poetry) immediately gained popularity and became a long-running program. It was aired daily just after the seven o'clock news in the morning. The themes or subjects of the poems were drawn mostly from current issues of the times. In order to maintain its number of contributions and its popularity, it eventually became a contest in which the entry read for the day was its daily winner.

According to Alunan, "the DYVL Puplonganun serves as a means of literary publication in the region since it went on air in the late 1970s up to the present." She explains that this is so because "weeklies and dailies are not too open to literary contributions." Consequently, the radio became "the only venue for literary exposure of a community which seemed to have abandoned its literary heritage" (3). Alunan further claims that "Waray public is still by and large oral-aural; it is still not a reading public" (3). She concludes that "the DYVL siday, in spite of its obvious shortcomings, is a rather unique affirmation of the exuberance of the literary spirit in Leyte and Samar" (3).

It may sound strange for many that an important body of literature such as poetry finds its way through a medium like radio. Yet poetry is a natural form for the radio because of its oral-aural appeal that produces a special impact. The spoken word has always been an instrument of information, entertainment, inspiration, argument, and persuasion. Traditionally, the spoken word is the very core of poetry, and the radio presents this word to an audience of millions. Hence, in spite of what Ong calls the technologizing of the word, Waray siday still emerged as a powerful folk poetry in Leyte in a strong regional culture fortified by ordinary folks-who 
speak of their origin and identity as opposed to the poetry in metropolitan cities like Manila where literature has been overtaken by the professionalization of writing at universities.

The communal aspect of the Waray radio siday fosters the production of poets in some sense that stands for the whole Waray society; reflecting the views and aspirations of the people at large and being essentially their culture; so that even if one individual poet is recognized as the composer or performer, he is really speaking not as himself, an individual, but as the voice of the community. As Ruth Finnegan mentions in her book Oral Poetry: Its Nature, Significance and Social Context, Marxists pointed out that "literature such as this may function as a potential weapon in 'the class struggle'-hence the folks' interest in popular literature; on how satirical writings can undermine even topple established authority; or how new ideas and policies can be consciously propagated through popular literary forms" (45).

Hence, DYVL Waray siday continued to flourish on the airwaves for more than 30 years, admirable and unique for such a media initiative.

\section{THE AFFECTIVE POWER OF SOUND: ORALITY AND AURALITY}

We can account for the orality and aurality of the radio Waray siday by studying its very nature. First, it is a broadcast or radio poetry adopted from the practice in the late 1950s through the early 1970s, which is likely the "Golden Age of Radio." As a medium of dissemination for oral history and oral tradition, radio has two main benefits: one is the capacity to convey the oral/aural nature of oral history and tradition, and second, the ability to reach a potentially much wider audience than the rather self-selecting field of, for example, readers of books. It is also vitally important because one does not have to be highly literate to absorb oral history or tradition on radio.

Radio's first benefit is as a sonic medium which utilizes orality, aurality, and affect. "Aurality" means relating to the ear or the sense of hearing; in radio terms, the aural aspect of a program denotes the acoustic landscape being broadcast and the innately intimate way we absorb it. In poetry, it may refer to sound devices, rhythmical patterns, and compression of the statement, as well as other elements that make up the sound of poetry. "Orality" refers to the fact and quality of oral/ verbal communication. Thus, it is a subset of aurality. It is also a subset of oral history and oral tradition. "Aural" language refers to language as we hear it, while "oral" language is what we say. The affect theory explains that the affective power 
of the voice (orality) combined with the intimacy of the listening process (aurality) results in a change of behavior realized through listening to reading of oral poetry.

"Affect" in this paper refers to how the orality and aurality of the radio Waray siday creates feeling and emotion that influence behavior. In the case of the radio Waray siday, the reader (broadcaster) exudes affect and the listeners pick it up. This affect may include the concepts of feelings, mood, and emotion. Psychologists are particularly interested in the interplay between affect and cognition. Accordingly, affect seems to influence every aspect of mental life (McHugh 193). In the study "Feeling, Emotion, Affect," Eric Shouse interestingly differentiates the three: feelings, emotions, and affect. According to Shouse:

Feelings are personal and biographical, emotions are social, and affects are prepersonal.

It means that a feeling is a sensation that has been checked against previous experiences

and labelled. While an emotion is the projection/display of a feeling. An affect is a non-

conscious experience of intensity; it is a moment of unformed and unstructured potential

... it is what determines the intensity (quantity) of a feeling (quality). (5)

In other words, when we listen to radio, we may also in our minds see, feel, and touch. Hence, it is the synergistic power of the voice that heightens the intensity and affective power of the radio Waray siday. As a result, the Waray siday becomes a sonic action or event rather than a printed page moving from the eye and to the ear, from the page and to the voice.

Based on the radio inclusive theory, aurality is central to radio theory. Aurality matches with film's "specularity." It refers to the listening-to-ness of the audience, the heard-of-ness of the performer (broadcaster), and the listening itself: the "listening that" and the "listening how" (Beck 1). This shows the link between the radio text (in this case the Waray siday), context, and reception. This describes the hybridity of the radio and its intertextuality. As listeners, we process aural data across sense modalities-an exploration into a multidimensional phenomenon. Hence, the words of poetry as we listen to radio stimulates our senses as they may make us "see," "feel," "smell" and "touch" as they reach our ears and enter our minds.

Hence, the Waray siday will be more appreciated if not just read with the eye. Stephen Ratcliffe posits that "sound (the sound of letters, syllables, words, lines) realizes when a poem is read aloud," that is heard by a reader or listener. A poem "read with the eye only, in private reading experience," registers just a part of "the poem's reality/being (presence)." Accordingly, "full presence, in the present, becomes realized only when poem enters ear," converting it into sound in the imagination or, more likely, aloud (3). Furthermore, when we read the poem silently, with eyes, we think semantic meaning, but if we truly "listen" to reading we will experience the 
Waray siday in its full three dimensions, as both visual text and sonic text, words on page and words in air. Hearing the sound of words on text restructures our consciousness. It achieves a third dimension of sense and affect. It combines both the visual dimensions (words on the pages) and the acoustic dimensions (sound of poetry). The third dimension which brings the two-dimensional text fully into the world: as articulated acoustic shape (sound-as-shape, the shape of the poem in the air/ear) - a shape that, until a poem on the page is read aloud exists only in potential (3). As Olson suggests when he writes that "a poem is energy transferred from where the poet got it . . by the way of the poem itself to, all the way over to, the reader-the reader who will, in hearing it, complete the circuit. Hence, reading aloud, and listening to reading, is vital to this realization" (qtd. in Ratcliffe 3).

The vocalization helps the reader to absorb the full meaning. Stephen Smith, an American producer of historical radio documentaries, notes, "the tonality and pacing of human speech carry a whole sub-text of meaning that can get lost on the printed page" (qtd. in McHugh 188). Meanwhile, Rosyln Oades, an Australian voiceover artist and practitioner of "verbatim" theatre based on oral histories points out the uniqueness of voice ... "The quality of an individual voice, carrying within it the influence of age, gender, cultural origin, education, lifestyle, psychology . . . in addition to an individual's particular speech patterns, mannerisms, vocabulary, volume, pace, habits, creates a very distinct vocal-print ... as unique as an individual's fingerprint" (188).

Listening to the radio, as opposed to reading a text, gives a sense not just of who is speaking, but also of the subtle dynamics and narrative rhythms of oral poetry. When the physical and aesthetic qualities of voice are combined to powerful substantive content, the effect can be captivating. The speech has a ring of authenticity: the excitement of an experience, re-lived and communicated without any additive nor reduction. In this case, the "audio is the text" and the "radio is the stage for performance."

In the radio Waray siday, people listen on two levels: to what one says, and more importantly how one says it. It is in the rhythmic rise and fall of the oral reading that the very nuance or essence of poetry, truth, quality and strength are revealed. The drift of sound evokes mood and develops the meaning of the text or poetry. The sound does not need to have a narrator. We just let the ideas flow from one to another together with the sonic elements. Both the cognitive and the affective aspects come together as we hear the poem being orally read aloud in a way that moves the listeners. As one listener comments, "the radio Waray siday evokes the feeling of belongingness that gives comfort like home which one can never experience from other mainstream literary pieces. The local color of poetry is really present in the Waray siday." ${ }^{3}$ These affective sounds subconsciously color 
how we hear the Waray siday being read aloud and how listeners understand the cognitive content or meaning of it. English media studies theorist Michael Bull and sociologist Les Back argue that "sounds are embedded with both cultural and personal meanings; sounds do not come at us merely raw" (191). Hence, no two listeners will have exactly the same mental picture when they hear a sound because sound itself is subjective. Radio listeners can easily tell whether a message is happy or not by the sound they hear. If sound itself can influence their mood and understanding, it makes sense that the infinite modulation of the voice and the expressiveness of the spoken word may also elicit an emotional response distinct from the meaning of the words themselves. In other words, audio is a powerful source of affect.

\section{THE ORALITY AND AURALITY OF THE RADIO WARAY SIDAY: ANALYZING THE POEMS}

Milton A. Kaplan in "Radio and Poetry" mentions that "poetry is a natural form for the radio because intrinsically it has the oral-aural appeal needed for effective broadcasting" (271). Traditionally, the spoken word is central to poetry, and the radio presents this word to an audience of millions, hence radio is controlled by the heterogeneity of the audience and the physical limitations of the ear.

The radio Waray siday is a kind of poetry that is dependent on the ear. As a regional traditional poetry it is different compared to other poetry in many ways. Firstly, the Waray siday read over the radio is likely performed differently, thus changing its whole style and trend of its poetical composition. Kaplan points out in "American Speech in Radio Poetry" that "though the radio is the natural medium for poetry, the poets are encouraged to change their style, for the radio must at all times be clear and simple" (28). For instance, for immediacy of impact, DYVL, where the radio Waray siday is aired, encourages contributors to achieve a new directness of approach to their poetry as evident in the siday. The power of its idea or content is expressed in fewer words, a quality urgently needed in radio where no time must be wasted. On the radio, the siday poet is generally limited in time. He does not have the opportunity or luxury of time for an elaborate development of his theme. Hence, the radio Waray siday is compressed. This must be the very reason why the DYVL radio insists to limit as possible the Waray siday or poem to three-five stanzas only in which some radio siday contributors find it hard to meet. However, through the siday's conciseness or compression, the siday poet finds happiness with his form for his didactic purpose. 
Secondly, the radio Waray siday caters to a wide and extremely heterogeneous audience, hence it cannot depend on the free verse. DYVL radio does not accept this as siday. Though the radio Waray siday does not always have regular versification, the rhythm is always there. Based on a listener's comment, "when subjected to a poem scansion, the radio Waray siday does not have definite meter or rhythm, but consistent with the use of rhymes. These rhymes contribute to the melodious feel that are so easy for the ears to catch when heard. This may be the reason why the community folks get hooked to listening to the siday." Distinctively, the radio Waray siday is done in a form that fits into the aural pattern of broadcasting. The lines in other words are actually arranged for convenience of delivery. According to Kaplan, "inasmuch as the poetry is written for the ear, the pattern of the verse on the page is not at all important. Radio poets, therefore, have developed what may be called illumined or poetic prose, a form which appears as prose on paper but strikes the ear with the tension and cadence of poetry" (272). Hence, the radio Waray siday does not strictly adhere to the conventions of the traditional siday in which "traditional poets were interested in its grammar and syntax; attempted dictionaries; sought purity of expression" (Alunan et al. 5); "they keep a sharp ear out for the fine turned phrase, and practice precision of imagery and accuracy of tone" (7), instead the siday has evolved into a distinctly new form of poetry on the radio. Thirdly, the radio Waray siday presents ideas in simple, everyday words but not far from poetry. One source comments, "the diction used is simple and easily understood." "The siday is very literal in which anybody can relate since it uses day to day language," adds another. ${ }^{5}$ Another listener remarks, "the radio audience who are ordinary folks can easily comprehend without much imagination and interpretation because the siday uses plain and simple language." ${ }^{6}$ Indeed, the kind of language used makes it easier for the radio listeners to easily assimilate or understand the radio siday.

A number of radio Waray siday illustrates orality and aurality, to find out the distinct oral and aural qualities the siday has as an oral poetry, and finally, to see the interplay of orality and aurality in creating sense and affect that makes it a powerful poetry in Leyte. Incorporated are observations and reactions of some radio Waray siday listeners composed of college students, university instructors, and ordinary folks. $^{7}$

First, let us examine the radio Waray siday entitled "An Kinabuhi han Tawo" by Rogelio O. Jomadiao, broadcasted in 1993 and translated as "Life of Man" by Chris Agner (Alunan, et al., Mga Siday han DYVL, 2005, p. 128). Jomadiao is an avid and loyal practitioner of the DYVL siday. ${ }^{8}$ 


\section{An Kinabuhi Han Tawo}

Kinabuhi han tawo, puno hin misteryo,

Damo nga pakiana, nasulod ha ulo,

Hin-o ba gud hira, ikaw man ug ako?

Kay ano may pobre, ug sugad man riko?

Inin kinabuhi pareho hin binlad,

Guhit han kapalaran in barubaliskad,

Bisan pa daw ikaw in maabilidad,

Ayaw la pagtapud, bangin ka matuwad.

Inin kinabuhi pareho hin balod,

Nadalagan ha labnasan, makuri maabot,

Pareho'n pangabuhi, nauswag nalulunod,

Danay naman humubas, danay naman taob.

Kita-a daw, sangkay, kaliding hit awto,

Ito pareho la kinabuhi hito'n tawo,

Samtang nakaliding, kapalaran tinitigo,

Kon kinabuhi tiatras o tikadto.

Pero'n importante di kita magturaw,

Samtang nga buhi pa ug nakakagakaw,

Basta la malimpyo an kina-on ha kinaadlaw,

Diyosnon nga tinguha naunhan, nabawbaw.

Para ta maabot, hingyap nga kauswagan,

Kita pagsakripisyo, pagtadong hit dalan,

Malimpyo nga tinguha, mayor pa'n bulawan

Kinasingkasing nga pag-antos, dayuday naunhan.

\section{Life}

A person's life is full of mysteries Lots of questions come to mind, Who really are they, you and I?

Why are there poor as well as rich?

Kritika Kultura 35 (2020): 132-153

(C) Ateneo de Manila University

<http://journals.ateneo.edu/ojs/kk/> 
Life is like rice being dried.

The lines of fate ever turning.

Even if you are talented,

Don't be too sure, you could stumble.

Life like the waves,

Rushing to shore, impossible to catch.

Like one's life prospects, flowing and ebbing,

Sometimes it's dry, and sometimes high.

Look, friend, at the tires of a car,

That's also how life goes -

As it rolls, it's anyone's guess

If life will move backward or forward.

What is important is that we don't lose hope

As long as we're alive and able to move about.

Enough that what we eat every day is clean,

Our purpose ever turned to God above all.

So to achieve the progress we desire,

Let us sacrifice, follow the straight path.

A pure intention's more precious than gold,

Heartfelt sacrifice is often rewarded. (Agner 128)

Jomadiao's poem revolves around the metaphors of life as its theme. It begins by raising a rhetorical question that deals with the issue of identity-presenting the economic class through the binary opposite concerning the rich and the poor: "Hin-o ba gud hira, ikaw ug ako?" ("Who really are they, you and I?") "Kay ano may pobre ug sugad man riko?" ("Why are there poor as well as rich?") which is answered by the persona. The siday poet makes use of metaphors to give the allusion of the mystery of life such as "Ininkinabuhi pareho hin binlad" (Life is like rice being dried), "Inin kinabuhi pareho hin balod" (Life like the waves), "Kita-a daw, sangkay, kaliding hit awto, Ito pareho la kinabuhi hiton tawo" (Look, friend, at the tires of a car, That's also how life goes-). One folk observes that "the siday is rich with images through its metaphors that produce a certain affect." The siday poet equates life with rice grains (binlad), waves at sea (balod) and wheels of a car (kaliding) for rhetorical effect. These words create visual images or imagery representing contrasts, inconstancy, cyclical, irregular conditions depicting the ups and downs of life as well as evoke emotions. The richness of metaphor is a noticeable quality of the Waray siday. This Waray siday ends with a conclusion that 
if one wants to succeed in life, one has to face it with patience, perseverance, and prudence. As one folk puts it, "this siday presents Waray culture-resilient and hopeful despite life's difficulties."

Observe the well-formed rhymes in each stanza. Notice how the sound of words (aurality) itself in the four-line stanzas gives pleasure to the ear. Jomadiao's siday follows the quatrain rhyme scheme that produces smooth melodious lines. Each stanza contains four lines following this rhyme scheme: AAAA, BBBB, CCCC, DDDD, EEEE and FFFF. All the stanzas use an exact rime, with similar or same vowel sounds, however, the second line of the third stanza uses an off rhyme or imperfect rhyme in the succeeding words such as balod, maabot, nalulunod, and taob. As one listener observes, "the radio Waray siday if examined closely has indefinite, irregular meter and rhythm, but consistent with the use of rhymes." The versification may not be so perfect, however; consonant words with similar sounding endings are employed in this siday to give that rhyming effect that contribute to its aurality. A listener comments, "the poet's creative use of rhyming words at the end of each line makes the siday more melodious to hear, and therefore, catches the interest of the radio audience member." ${ }^{9}$ Accordingly, rhyme is a distinct quality in the siday. As another listener adds, "the siday does not have perfect rhymes, yet, the way the words are played creates that certain melody and rhythm emphasized more when read aloud." "Listening to the siday gives us a melodious feel which makes it more appealing to the senses. The melodious feel adds color to the meaning of the siday," declares another radio audience. ${ }^{11}$ Perhaps, the siday has certain musicality of its own.

In Jomadiao's siday, the rhyme scheme is never unnatural or forced. Commonly noticeable are the repetitive or alliterative nature of the lines, words, and phrases, and parallel construction found among radio Waray siday, "Ininkinabuhi pareho hin binlad, Inin kinabuhi pareho hin balod, kinabuhi, pangabuhi"-which is a characteristic shared among many Waray siday poets for the purpose of easy understanding so that even the inattentive listener finally catches up or grasps the meaning of the lines. As observed by a listener, "the siday uses anaphora as a poetic device which makes the siday more emphatic." ${ }^{12}$ Accordingly, "the repetition of some words in each line serves as stylistic effect that gives emphasis to the word used which attracts the listeners' attention." ${ }^{13}$ The repetitive or alliterative nature of the lines, words, and phrases found in the siday contribute to its orality and aurality that make it more emphatic, creating a forceful and powerful effect in the minds of the listeners.

This may serve as an illustrative example not only of the form of early Waray poetry but also of the beauty of Waray language. As one listener notes, "the radio Waray siday connects easily with the listeners because of the vernacular language 
that is used. Hence, because of this familiarity with the language, the audience feel oneness with the speaker of the poem. The siday becomes powerful as it reflects the voice of the common folk with its artistic value." ${ }^{14}$ The natural alliterative, consonantal, and assonantal nature of the Waray language combined with the siday's rhymes and meter produce the mellifluous sounds that give delight to the listeners' ears. The sound of words in itself gives pleasure and enjoyment.

T.S. Eliot from "The Music of Poetry" reminds poets that "the music of poetry is not something which exists apart from the meaning" (qtd. in Kennedy and Gioia 170). Accordingly, the poem's music which is the distinct way it sounds, is an essential element to create sonic effects which makes it different or separate from prose (171). It is an integral component of its art form. This sonic element helps convey the poem's main idea or theme and enhances the literal meaning of each line in the stanza. This comprises the poetic features such as rhyme, rhythm, meter, alliteration, rhetorical devices, and so forth. Poems are often developed using these to create sound patterns or the so called rhythmical effects. Minot mentions that "rhythm is like heartbeat in poetry that gives life to it" (qtd. in Kennedy and Gioia 6). Since poetry as a genre in literature has its roots in the spoken word, sound becomes an important aspect of this art.

To relate it to the Waray poems, maybe one element of the siday that makes it popular among the Waray folk in spite of its simple form is the sound of language found in its poetry. Vilches describes "Waray language as distinctively polysyllabic. This fact explains the naturally alliterative, consonantal, and assonantal nature of the language" ("Waray Poetry" 59). Obviously, the Waray language in the siday is dominated by these three vowels, that is, /a, i, u/, for the vowel /e/, remains a foreign sound to the Waray tongue. Waray has a near open front, short vowel, but it is different from the /æ/ in the English word, mat. It has an extreme open front vowel /a/, a close back semi-rounded vowel /o/, a close mid-back unrounded vowel $/ \mathrm{u} /$, a close mid-extreme front vowel /e/, a close extreme front vowel /i/, and close central semi-rounded vowel /y/ (Oyzon). This tendency of Waray vowels to be fronted could explain why linguists describe them as "tensed." These vowels produce a distinctive sonic sound typical to the Waray which adds more uniqueness and color to the sound (aurality) of the siday. According to one Waray listener, "the siday read over the radio produces certain thrill that affects our senses because it is recited by a native Waray speaker. The man behind the microphone has that certain twang, distinctly Waray. If it had only been recited by a non-native speaker, the effect would have been different." ${ }^{15}$ The delight lies in the beauty of the Waray language and how it is spoken or sounded.

The Waray language as spoken always bears the quality of being sonorous, tensed, and high-pitched, making it more forceful, emphatic, and powerful. This 
can be attributed to soundscape or the geographical location of the place. The region's terrain is relatively flat near and along the coast. Its mountainous areas are mostly located in the middle portion of Samar and Leyte. Leyte's mountainous terrain covers most of the southern and southwestern portion of the island while the northern part is extensively flat. At the northwest part are scattered coastal flat lands. Samar is characterized by mountainous ranges with forests and deep valleys. Based on myths and legends, the Waray natives were mostly fishers and farmers who lived either near the coastal areas or in the mountains and forests. According to stories, since they basically work at sea or in the field and mountains, they were fond of yelling or bellowing, and have the tendency to be repetitious when communicating for they mostly found it hard to understand each other because of the characteristics of their place-bounded by the roaring of the sea waves, the deafening howling of the sea breeze or wind, and hindered by the far distant mountains and barriers. This could be the reason why the Waray even up to this day are characterized as constantly shouting or yelling, which is oftentimes misconstrued as being enraged. Based on an audience comment, "Waray is a strong language. When the Waray speaks, the tone seems angry and hostile. Possibly, this can be ascribed on how every syllable in every Waray word is stressed."16 This quality of loudness is typical and normal among the Waray which again has a unique effect on its aurality.

Moreover, through analyzing the Waray language, we can understand the nature of the people. As a medium of communication, the Waray language, tends to mirror the thought of its people. Father Alzina, a Jesuit priest, states, "the name Bisaya, if we derive it from the language of the people, means a happy man, good tempered and pleasant. This meaning is taken from the roots of certain Bisayan words such as 'saya', 'aya', 'caya' which mean the same thing, in a combined form make 'macaya', a good tempered man; 'maalicaya', a good-natured man with many friends; 'masaya', a cheerful man; 'himaya', bliss or contentment. Bisaya means a pleasant and happy man. The Waray, therefore, is carefree and sybaritic" (Vilches, Iluminado Lucente 12-13). This can be proven by practices that are existing in contemporary Waray society. For example in the rural areas in Leyte, after a day's work in the fields, men gather together to drink tuba, to tell funny stories, to sing to the accompaniment of a guitar. The townsfolk are also enthusiastic about celebrating fiestas and other feast-making activities; they make the gatherings alive by staging plays, sponsoring amateur singing contests and elocutions in verse. Among the Warays, a fiesta is an occasion to verbalize thoughts and sentiments in metaphoric language through poetry and songs (Vilches, "Waray Poetry" 62). However crude and unskillful these songs and poems may be, they are nevertheless indicative of the people's literary flair which we may say is evidently inherent among town folks. The Waray is the epitome of the Bisaya-fun, loving, warm, kinship-nurturing people of the Eastern Visayas archipelago, namely, Leyte, Samar and Biliran. 
Ata lighter tone, let us takea look at the radio Waray siday entitled "Nagtratraysikol" by Richard C. Labarda (Alunan et al. 30) or "Tricycle Drivers" as translated by Chris Agner.

\section{Nagtatraysikol}

Usa ka adlaw may ada ako hinkit-an

Mga nagtratraysikol ha kakalsadahan.

Balhason an lawas dida ha kasirakan

Dagmit nga luminya didto han paradahan.

Dayon sumarakay gintawag nira,

Kampay ha tuo, kampay ha wala.

Waray kaiha may awto nga pumarada

Ngan damo nga pasahero an sumakay ha ira.

Dagko nga mag-asawa sumakay han usa,

Traysikol hinmuyot ngan humiyos an goma.

"Mano, Mana, balhin na la kamo ha iba,

Goma patatangkopan ko, ipapaayad iton yanta."

May ada lalaki nga may tinugwayan nga bata

Dumangop ngadto han nagtratraysikol nga bata.

"Idoy, dad-a kami ngadto ha Kalye Naga,

Pero ha Kalye Apitong, hapit anay kita."

Maanyag na babaye akon liwat hinbati-an

Nga nagsiring ngadto han iya mga kasangkayan,

"Mahimo unta, pili kita hit' at' sasakyan,

Kay di ko gud karuyag, lasaw hitapsikan."

Duha nga babaye, batan-on pa hira,

Tinawag nagtratraysikol ngan pinakianhan,

"Mano, an amon igbabayad pira kon biyahe

Pakyawon namon, upod it' am' karga?”

Lima na batan-on nga lalaki an sumakay

Hin usa liwat nga traysikol, pagkit-on guti-ay.

"Mano, ay' kabaraka. Duha iton masaluro anay,

Samtang usa ha amon ha gawas makalab-itay."

Kritika Kultura 35 (2020): 137-153

(C) Ateneo de Manila University

<http://journals.ateneo.edu/ojs/kk/> 
May tawo liwat nga damo mga karga

Kumampay hin traysikol ngan dumaop ha iya.

"Damo it' ak' dara, butangi pati ha may manibila,

Kay akon malingkod na la ha luyo hit' silyeta."

Lagas na babaye nga kun mangiwa mahinay

Ha usa nga traysikol hiya sumakay.

"Budoy, unta padalagan himoa nga mahinay

Kay bis' ako sugad di ko pa karuyag mamatay.”

Nagtatarotaghoy, lalaki nga gwapohon,

Sumakay hin traysikol, karuyag lumarga dayon.

"Brod, pedalan paspasi gad naton

Kay ako naglalanat hin importante na higayon."

Urhi na sumakay, babaye nga mistisa

Paglingkod ha traysikol, umabre han pitaka,

"Mano, iya, pasahe ko uno singkwenta,

Kay buotan ka man, dudugangan ko hin singkwenta."

Ha kakalsadahan hira hinkikit-an naton -

Nagtratraysikol ha adlaw ug ha kagab-ihon.

Sarakyan nira damo an ngaran naton

Traysikol, potpot, de-pedal, de-kabron

Mga nagtratraysikol ha kada pamasada

Lain-lain nga tawo ginsisirbihan nira,

Pasahe naguti-ay, ibinabayad ha ira

Pakabuhi nagtuptop, pagbuhi ha pamilya.

\section{Tricycle Drivers}

One fine day, this is what I saw,

Tricycle drivers plying the streets of the town.

Under the sun, sweaty all over

Quickly joining the queue at the terminal.

Started calling out to the passengers,

Waving to the right and to the left.

Very soon, a car came around

Some passengers alighted and got into them.

Kritika Kultura 35 (2020): 138-153

(C) Ateneo de Manila University

<http://journals.ateneo.edu/ojs/kk/> 
A big fat couple boarded one,

The tricycle sagged, its tires deflated.

"Mano, Mana, please transfer to another cab.

The tires need mending and the spring fixed.

A man leading a child approached

A driver who was just barely grown.

"Idoy, please take us to Kalye Naga,

But let's drop by Kalye Apitong on the way."

I overheard a pretty lady

Say to her friends,

"If possible, let's choose our ride,

For I really hate being splashed by these mudholes."

Two women still young,

Hailed a tricycle and asked,

"Mano, how much to hire you

To carry us and all our baggage?"

Five young men also got on

A tricycle that seemed too small for them.

"Mano, don't worry, two will sit on our lap,

And one of us will just hang on somehow."

There's the man carrying quite a bulk,

Called for a cab, which quickly came.

"I've lots of luggage, load them up to the wheel,

I'll just stay in the little seat, behind the driver."

An old lady who moved ever so slowly

Boarded a tricycle.

"Budoy, may I request you to run slowly,

Though I'm old, I'd like to live a little longer."

Along came a good looking man, whistling,

Boarded a cab and wanted it to go quickly.

"Bro, step on the pedals fast,

I'm really after important things."

Last for the ride was a mestiza,

Once seated, she opened her purse.

Kritika Kultura 35 (2020): 139-153

(c) Ateneo de Manila University

<http://journals.ateneo.edu/ojs/kk/> 
"Mano, here's my fare, one peso fifty cents,

But because you're good, here's fifty cents more."

In the streets you'll see them always -

Running their tricycles, night and day,

Their cabs go by many names,

Tricycle, putpot, de pedal, de cabron.

These tricycle drivers, each of their run.

Serve different kinds of people.

The meager sum that is paid to them

Is honest work to feed their families. (Agner 30)

In this siday, we get a pleasant change of performance because of its unusual light tone that is extraordinary for the radio Waray siday, which has a tendency to criticize, complain, bluster, moralize, or sermon. For once, the siday poet is not looking for fault.

The tricycle is the most popular means of transport in small towns and cities, especially in the rural areas or provinces of Leyte and Samar. In this siday, Labarda meticulously symbolizes the different characters in the community whom the tricycle driver does service, as perceived by the persona. His observations suggest amusement for both driver and passengers. The unique presentation of the different characters or personalities of the passengers who are perfectly placed in their respective position in the stanza sequence shows the binary contrasts between the fat and the thin, the hasty and the slowpoke, and then the parade of the other kinds of passengers, like the beautiful lady who is demanding and fastidious on the tricycle she will ride on, and the old woman who wants the tricycle driver to drive slowly, in contrast to the handsome bachelor who wants the driving to be extremely fast, the canny guy who has two places to visit for a fare of one route only, the man whose enormous and excessive baggage leaves him no seat in the vehicle, and then the last, a mestiza lady who gives an extra tip to the driver. Interestingly, as one observer notes, that "the siday presents a contrast between an old woman who wants the ride to be so slow, while the young man wants it so fast." ${ }^{17}$ "Ironically, we can say that the woman seems to slow down one's death or journey to old age, while the young man, wild and free cannot see yet the importance of life", she adds. Indeed, the siday shows a kaleidoscope of various people from all walks of life, in particular, coming from the low-income strata of society whom the tricycle driver serves daily. 
The language used in this siday of Labarda is clear, simple, and direct. It makes use of everyday words, the words of common tao, which makes it easier for the town folks to understand.

Reading the siday aloud creates a vivid and living picture of the different and ordinary folks the tricycle driver encounters each day in his work. The radio listeners are able to relate to such social and cultural affect since they come from the same place or community. The common everyday language used to describe these different ordinary individuals creates a local color that resonates in the minds of the listeners, making them experience indirectly the provincial atmosphere as well as relate to the characters mentioned. Just like any human being, the tricycle driver is projected as any other individual, like any of his fares, earning a meager and insufficient income, an honest living. One listener reacts, "this siday is somewhat giving tribute to the tricycle drivers as shown in the last two stanzas." 18 The tricycle driver's dignity is somehow exalted at the end. Labarda's siday is good-humored, and has a sense of drama which is much enhanced as the sonic action is performed.

Though the siday attempts to have the AAAA, BBBB, BBBB, BBBB, AAAA rhyme scheme in a quatrain at the end of every line in each stanza, it is not able to maintain it towards the sixth and eighth stanzas. Nevertheless, even if the rhyme is irregular, its impact is reached once the siday is read aloud on the airwaves depending on how it is read. Through the interplay between orality and aurality of the sound, it allows us to hear what people are talking about, and hearing their voices, as opposed to reading their words, can give information about their attitude, mood, geographical and cultural origin, age, and maybe more. In fact, the same words can mean different things when shouted and whispered. Based on a listener's remarks, "the versification of the radio siday seems imperfect, yet the beauty lies on the way it is being read on the radio as the voice reaches the ears of the listeners and creates that certain sense and affect." ${ }^{19}$

Stephen Ratcliffe in Listening to Reading emphasizes that sound in poetry may be thought of as an acoustic dimension that exists on the page; however, its sound is realized when the poem is read aloud (heard by reader and listener), which brings the text fully into the world: as acoustic shape-a shape that, until the poem on the page is read aloud, exists only in potential (3). Hence, this realization is only achieved once the poem retrieved from the poet goes all the way over to the reader down to the listener, who will in hearing it complete the circuit. Reading aloud is crucial to this sense of consciousness.

Moreover, the siday poet utilizes the direct speech regularly found in lines 3 and 4 of every quatrain in the siday to create a natural dialogue between the tricycle driver and the passenger as depicted in the following: (lines 11 and 12, dialogue

Kritika Kultura 35 (2020): 141-153

(C) Ateneo de Manila University

<http://journals.ateneo.edu/ojs/kk/> 
of the driver): "Mano, mana, balhin na la kamo ha iba, goma patatangkopan ko, ipapaayad iton yanta."; (from lines 15 and 6, dialogue of the couple): "Idoy, dad-a kami ngadto ha Kalye Naga, pero ha Kalye Apitong hapit anay kita"; (from lines 19 and 20, dialogue of the fastidious beautiful lady): "Mahimo unta, pili kita hit' at' sasakyan kay di' ko gud karuyag, lasaw hitapsikan."; (from lines 23 and 24, dialogue of the young ladies): "Mano, an amon ig babayad pira kon biyahe pakyawon namon, upod it' am' karga."; (from lines 27 and 28, dialogue coming from the young gentleman): "Mano, ay kabaraka. Duha iton masaluro anay, samtang usa ha amon ha gawas makalab-itay.; (from lines 31 and 32, dialogue from the man with excessive baggage): "Damo it' ak' dara, butangi pati ha may manibila, kay ako malingkod na la ka luyo hit' silyeta."; (from lines 35 and 36, dialogue of the old woman): "Budoy, unta padalagan himoa nga mahinay kay bis' ako sugad di ko pa karuyag mamatay.; (from lines 39 and 40, dialogue of the handsome man): "Brod, pedalan paspasi gad naton kay ako naglalanat hin importante nga higayon."; (from lines 43 and 44, dialogue of the mestiza lady): "Mano, iya, pasahe ko uno singkwenta, kay buotan ka man, dudugngan ko hin singkweta." A listener remarks, "this siday of Labarda is dominated by narrations and dialogues." ${ }^{20}$ Most of the folks comment that this siday is a pure prose or a narrative poem as it relates the everyday life drama and struggle of the tricycle driver. Another listener adds, "it tells a story. It looks like a pure prose, however, with its form and rhyme scheme, it remains a poem. It is prose poetry." ${ }^{21}$ The presenter in the audiotext read Labarda's siday with a dramatic twist as she used emphatic stress or emotional intonation in these dialogues to draw a more one on one intimate exchange of thought between the driver and the passengers. The articulation of these dialogues by the presenter evokes a natural, closer, and more personal acquaintance with the persona in the siday. Here, the presenter varied her voice to show the contrast of the different characters mentioned in the siday as well as to create dramatic effects. As one listener comments, "with the touch of dialogues between the driver and his passengers in the siday, the siday poet or broadcast anchor make the experience more alive as she bestows voices to the tricycle driver and the various passengers the driver encounters every day. This made the phenomenon more emphatic and real." ${ }^{22}$

And lastly, let us consider another radio siday entitled "Pamatron" by an anonymous contributor from San Miguel, Leyte. In English it is "Attending Fiesta" as translated by Aurora Casimpan (Alunan et al. 56).

\section{Pamatron}

Bulan han mayo, bulan nga marisyo,

May ada santakrusan ug Flores de Mayo.

Kritika Kultura 35 (2020): 142-153

(C) Ateneo de Manila University

<http://journals.ateneo.edu/ojs/kk/> 
Patron na liwat ha mga barangay ug mga bungto

Makikita mga auto pula an plaka, tigaman kanan gobyerno.

Mga empleyado ispesyal nga bisita han barangay captain. Alas onse pa la nasakay han kanan bungto ambulansya.

Pasyensya la anay an mga grabi kay diri madudul-ong -

Pamatron ginpasiurog kay ha pag-uli may ada bring home.

Ha mga purupamatron hi-tech na kaupay

Kay may ada ambulance nga nagbabantay

Pagdara ha lock-up cell han nagdadaros nga hubog,

Pagdul-ong ha ospital hadton nagkakabubukog.

Ha mga opisina, an mga tawo pasyensya la anay,

Balik nala buwas kay mga empleyado namamatron.

Andam an ambulance ug garbage truck pagpasakay

Hit patron ma-enjoy, han bahalina tagay-tagay.

Didto han lamisa, tikang an pagrakya.

Ha sala may nasayaw han la jota ug kuratsa.

Han ligas waray magpakabalik ha mga opisina,

Kay nanhimalanga han gallon, han baso sinalo-salo.

Hi Juan de la Cruz, kairo, amo an alkansado,

Bisan la han gasoline ha kanan gobyerno mga awto.

\section{Attending Fiesta}

The month of May, month of revelry,

There's the Santacruzan and the Mayflower festival.

It is fiesta time in the barangays and towns

Red plate cars are seen, sign that they're government owned.

The employees are special visitors of the barangay captain.

At eleven o'clock they board the town ambulance.

The critically ill can't be brought to the hospital-

The fiesta comes first because there's "bring home" afterwards.

Fiestas are getting hi-tech nowadays

Because an ambulance is always on standby

Kritika Kultura 35 (2020): 143-153

(C) Ateneo de Manila University

<http://journals.ateneo.edu/ojs/kk/> 
To bring the disorderly drunk to the lock-up cell,

Or to the hospital, those with fishbone stuck in their craw.

In the offices, people just have to be patient,

Come back tomorrow for the employees are off to fiesta.

The ambulance and garbage truck are ready to transport us

To enjoy the fiesta, to drink the bahalina.

At the table, the merrymaking commences.

In the sala there's dancing, the la jota and curacha.

No one returns to the office in the afternoon,

Engrossed with the gallon, and passing the glass.

Only poor Juan de la Cruz is shortchanged,

Even just for the gasoline of those government-owned cars. (Translated by Casimpan, 56)

The Warays, just like any Filipino, love fiestas. The word "fiesta" usually brings a smile to every Waray. A fiesta is a special time with friends, a time for fellowship, food, and lots of activities. The siday title "Pamatron" is a verb which connotes an invitation to a feast. It is a common expression among the Warays to say, "pamatron" which means "come or join our fiesta." The "fiesta" or "patron" in Waray, which may also refer to the saint being venerated in the fiesta, is Spanish in origin. Leyte, as part of the influence of Spanish colonization, is predominantly a Roman Catholic province. Traditionally, the fiesta is already a part of their life and they set aside a certain day to remember and worship a particular saint with processions and celebrations. Hence, the fiesta has become a Roman Catholic feast still popular in the Leyte and Samar provinces. Long after the religious ritual is completed, people eat, drink, and enjoy the rest of the day. However, the original honoring of the saint which is its primary purpose has been largely forgotten. It seems that today they do more harm than good. Unfortunately, more often than not, excessive drinking harms the festivities. The bad practices in the fiesta observed among the Warays is the primary content of this siday.

For Waray folk, "this siday is culture-centered which depicts not only the Waray culture, but also the attitude of the Waray folks towards fiesta. It describes the Waray community on this certain occasion as they celebrate such tradition." "Everything about the siday is factual. The scenarios are not results of creative thinking, instead, they are based on real occurrences during fiesta celebrations," added another. The siday portrays a community that is carefree, fun-loving, and fond of drinking. A celebration in the Waray region would not be complete without the bahalina or tuba, a popular drink in Eastern Visayas made from coconut tree sap. Moreover, 
the "bring home" among the Waray becomes a norm in every fiesta. Every fiestagoer is just as excited to go home with a bag full of "bring home." The more "bring home" one gets, the merrier and contented one becomes.

The language of this siday is now far different from the usual or traditional ones. It is interesting to note how the siday illustrates a community that has once been colonized and is now influenced by modernization and globalization as it incorporates some of the English terms such as lock-up cell, garbage truck, bring home, barangay captain, ambulance, hi-tech, ma-enjoy, and Spanish terms such as Curacha, La Jota, alas onse, and Juan de la Cruz, which is what Ong celebrates as the technologizing of the word. In the siday, the mention of Juan de la Cruz is an allusion that refers to Filipinos. The present Waray siday creates a fusion of the languages of the colonial masters centuries ago in the history of the Filipinos. This evidently shows how the Waray language in the siday has transformed or changed over time. As Pablo Neruda puts it, "El mundo ha cambiado, y mi poesia ha cambiado" translated as "the world has changed and so has my poetry" (Bagulaya 90).

"The style of the author is commendable," comments one folk observer. "The siday begins with jovial mood anticipating the merriments, surprises, and fun in the fiesta, but introduced smoothly a certain twist of theme with the introduction of ambulance," he adds. The first stanza describes the very rich culture of the Waray, such as Flores de Mayo, Santacruzan, fiestas inherited from the Spaniards, our colonizers. Who would have thought that this siday "Pamatron" attempts to criticize local politicians and errant public officials? Surprisingly, this siday comments on some social behavior of the community during fiesta. It shows an ironic experience of the malpractice or abuse displayed in the community over and above the festivity. Consequently, it is common among the siday poets to use pseudonyms or stay anonymous for it emboldens them in chiding or attacking local folk for their manners and immoral ways, and public officials who abuse their power. In this siday, the poet generously uses satire and a strong sense of irony and humor as he connects the subject to a current issue of the times prevalent in the community or against foibles in society. It seems that the satire is hiding behind the humor. The siday becomes the poet's weapon to ridicule political leaders and institutions and rile against certain social practices that bother the collective conscience of the public. It reflects the conventional themes of the siday, criticizing the weaknesses or shortcomings of humanity or society. It tries to remind the folks what they ought to know and do-a sort of eye opener.

The ambulansya in the siday becomes an object of ridicule as it is used symbolically to illustrate the many abuses through its many different functions in the fiesta-as a transportation to bring the employees to the house of the barangay 
captain during office hours (stanza 2, line 1), as a car to transport a very serious or dying patient (of stanza 2, line 3), to carry a rough and wild drunkard (stanza 3 , line 3), and as transportation to bring one who has stuck a fishbone in the craw due to greediness (stanza 3, line 4), consequently overriding the true function of the ambulance. Moreover, the siday shows the rampant corruption in the government. According to an audience comment, "although the siday depicts the festive traditions of the Waray, in another light, it is satirical." ${ }^{23}$ As someone adds, "the poet attacks the customary practices of the Filipinos in general of giving so much importance on guests who occupy higher status in society. Furthermore, this implies how people from different economic strata are treated in society. The siday portrays the universal truth of inequality between the audible and inaudible or the visible and invisible." ${ }^{24}$ The irony combined with humor creates a subtle eye-opener among the addressees as they are being lashed by the critical attack of the poet. The listeners experience a diverse kind of political and social affect.

The listeners' imaginations are stirred through lavish use of metaphor and imagery that construct color to the meaning, highlighted by sound when it reaches the listeners' ears. The bahalina, garbage truck, patron, kuratsa, gasolina, are not present and yet, as if one can visualize and see them move, one can indirectly experience a different dimension, a new consciousness one hears, smells, touches, and feels in one's life as listening to reading-the presence becomes present.

The ordinary experiences mentioned in the siday through its ordinary, everyday expressions transcend as the radio transforms these experiences into vehicles of biting humor, irony, and satire that spring from exaggeration of situations or circumstances. From this, the community absorbs an experiential dimension.

Some words are repeated frequently for emphasis such as "bulan han Mayo," "bulan na marisyo," "tagay-tagay," "sinalo-salo" which is familiar to the siday as characterized by its language. Since the radio Waray siday is meant for broadcasting or for the airwaves, it is rooted in common speech. Its language is informal and very often colloquial. Even if it is in verse, the language is generally conversational, simple, direct, often informal and idiomatic. In other words, the verses are simplified, direct because it is composed for the mass-audience. This is one of the reasons why the radio Waray siday is appealing to the experience of the average listener or the common tao. Noteworthily, one remarks, "the siday 'Pamatron' ends with a couplet: Hi Juan de la Cruz, kairo, amo an alkansado, Bisan la han gasoline ha kanan gobyerno mga awto. Such a remarkable move from an untrained poet." The audience cannot believe such a gesture from an ordinary folk composing this folk poetry. 
The common tao, or local folks, are the target audience, not actually the intellectual elites. Hence, the figures of speech emanate from everyday experiences of the common folks. Figures of speech, particularly, are strong and simple, for the ear cannot be expected to assimilate or understand highly deep or abstract imagery. Language is lucid, vivid, and unpretentious. The simplicity and directness of the verse as it is read aloud to an intent audience of his own people carries with it much power. This kind of poetry is dependent on the ear. Sound infuses the word with life. The words are the words of the people talking, but more fundamental than that, the rhythm is the rhythm of the people talking. It is the rhyme that sets poetry from ordinary conversation, bringing it closer to music.

In "American Speech in Radio Poetry", Milton Kaplan clarifies that "there is no retina of the ear to carry over syllables as the eye does images; hence the radio poet's imagery must never be too intense, or shot at the listener too fast. It must be directly communicable and easily assimilated, or it has no right to be on air" (31). Hence, poetry must use the idiom of common speech. Similarly, Hooks in Korina Jocson's work, "Literacy Learning, Empowerment and Poetry," says "poetry is a privileged speech-simple at times, but never ordinary" (38). T.S. Eliot cautions "poetry must obey: the law that poetry must not stray too far from ordinary everyday language which we use to hear. Whether poetry is accentual or syllabic, rhymed or rhymeless, formal or free, it cannot afford to lose its contact with the changing language of common intercourse" (qtd. in Kaplan 32). Hence, it must still retain its versification. In other words, poetry has to be simply understood or else reading it will be meaningless and futile.

Lou Orfanella in "Radio: The Intimate Medium" emphasizes that radio as a medium for poetry has this "special power of intimacy, a one-to-one connection that no other medium can match" (53). It is able to reach people through a single sensehearing. By its distinctiveness through sound, imaginatively used, the listeners are aroused to generate in their minds a picture and imagination is reached through the ear. It has the "power to individualize its presentation within the mind of each and every listener-an intimacy and a shared vision that it creates" (55). As Morrow puts it, "radio is a reflector, not a projector"- they are able to reflect society; we are not the poetry, we are the amplification of the poetry" (qtd. in Orfanella 53). This simply means, it is the medium that carries the word that paints the scene or event and stirs the emotion that makes the listeners imagine, feel and empathize with the poet. Poetry is the most beautiful form of human speech that operates through the power of words.

According to Robert Pinsky, "there is a special intimacy with poetry because ... the medium is not the expert's body, the medium is the audience's body. The reader's breath and hearing embody the poet's words. This makes the art physical, intimate, 
vocal, and individual" (qtd. in Street 3). Further, poets have used sound as part of their imaginative resource: indeed poetry is sound. Radio has the power of the medium to act as a voice of the poet. Sound has the capacity to take the listener out of the everyday by making images dance across the imagination. Sound offers a portal through which a deeper, often inarticulate consciousness can be glimpsed, that reaches the deeper recesses of consciousness. For instance, in the radio Waray siday Pamatron, the word ambulansya has no sound, but on radio, though we cannot see it, we can hear it, as if it is real, as if it is present. The poetry of sound is that the magic is an extraordinary effect that happens sometimes about particular tones or timbers of sound, how they strike the ear, and about how they juxtapose against another piece of acoustic energy.

The above-mentioned radio siday concretize the present milieu of the Waray community. As one observer notes, "they depict the kind of community common in Eastern Visayas. The radio siday became an avenue to portray the lives of ordinary folks. It serves as a medium of expressing the culture of our province through artistic poetic elements." ${ }^{25}$ Another reacts saying, "the siday realistically without inhibition illustrates the Waray culture, the place, its people, their sentiments, and their aspirations." ${ }^{26}$ The radio sidays do not only produce the expanding milieu of the Waray community, but also reflect the concerns of this community as it produces a recreated and reformed community.

\section{RADIO WARAY SIDAY: A REVITALIZED POETIC FOLKLORE}

The experience of poetry as sound demands craftsmanship, a training in rhythm, meter, phonology, pitch, stress, and intonation. In using these words, we could equally be describing the making of radio poetry. It comes down to this fundamental: we hear with our ears, but listen with our minds, just as we see with our eyes, but read with our brains. So it is that an essential point linking listening to reading is that they are interactive: the poet's relationship with his reader, like the radio producer's relationship with his listener is one of collaborative partnership through the imagination. This can be intellectual communication, brain to brain, or it can be impressionistic, the effect produced by sounds in an abstract way, the emotional response evoked by sounds (aurality). In visual terms, the power of color and form in painting evokes mood and emotion. The aesthetics or color of sound manifests effects that relate to the subconscious and personal circumstances of the listener. These sounds can imply the presence of people or things not present in the visual frame. Sound encourages us not only to imagine visuals in our minds but also evokes emotions and feelings, creating a singular experience for each listenerunique and special affect. 
These sensuous sounds found in the aesthetic elements of the Waray sidayphonetic, rhythmic, symbolic and morphological-resonate and echo in the listening ears and stir the imagination and emotion through the interplay of orality and aurality created by the visual (words) and the voice (sounds) that capture local color and sensibilities, cultural characteristics, traditions, values of the land, people's sentiments and aspirations, thus creating a peculiar affect among the people of the Waray region. Through the technologizing of the word, the radio Waray siday promotes and perpetuates literary and cultural heritage inherent among its people. Intertwining natural and communal characteristics, combined with the merging its orality and aurality, are the reasons why the radio Waray siday creates revitalized, modernized, and powerful poetry in Leyte.

The listening experience of the folks which was an augmented virtual listening, a form of aurality, strikingly made a great impact on the dissemination of the Waray siday. The radio as an ephemeral, ubiquitous, and intimate mass medium raised the cultural awareness in the region which eventually revitalized a dying language and literature. The Puplonganun program made the siday a revitalized, revolutionized, and democratized folklore that was more accessible to everyone in the region with the sound-based medium. Furthermore, radio created closeness between simultaneous listeners who constituted the imagined community through the intimacy of the human voice. The oral-aural nature of the radio did not just stimulate the imagination, but stirred one's innate pleasure which helped build a strong emotional attachment to the sonic medium itself. Through the sonic experience, there emerged a shared consciousness, experience, and imagination as the audience reacted to the radio Waray siday. 


\section{Notes}

An earlier version of this article was presented in the 2017 Kritika Kultura Criticism Workshop, held in Ateneo de Manila University.

1. Stephen Ratcliffe. Listening to Reading. State University of New York, 2000.

2. Ten (10) students who were English majors and seven (7) teachers from the Languages and Literature Unit who were former students and current colleagues of the researcher. They were purposively chosen for the interview as they were accessible to the researcher and they too had knowledge about regional poetry and had experienced listening to the siday on radio. The interview procedure was the same for both the students and the teachers. The students and the teachers were gathered separately in a classroom for the interview which was conducted on a separate day. The interview was made informal in order to lessen the anxiety of the informants. Firstly, an orientation was given about the study. The researcher recalled to the informants the popularity of the radio Waray siday and asked them about their respective experiences in listening to the same. Later, the informants were made to listen to the representative samples of the radio Waray siday. After listening, the researcher asked them questions about the experience of listening to the radio Waray siday. The informants were free to give their reactions, comments, and interpretations of the radio Waray siday.

These informants, that is, the students and the teachers were interviewed all together but at a separate occasions and some wished to remain anonymous.

3. Anonymous (English teacher 5 ), in personal communication with the author. October 13, 2017.

4. Permejo, Eugenio (college student, English major), in personal communication with the author. October 15, 2017.

5. Mengullo, Florenza Mae (college student, English major), in personal communication with the author. October 15, 2017.

6. Anonymous (English teacher 4), in personal communication with the author. October $13,2020$.

7. Some informants did not want to be named. They want to remain anonymous.

8. Napoles, Rogelio (college student, English major), in personal communication with the author, October 15, 2017.

9. Nierves, Arian Mae (college student, English major), in personal communication with the author, October 15, 2017.

10. Anonymous (college student, English major), in personal communication with the author, October 15, 2017.

11. Oncog, Rian Sid (college student, English major), in personal communication with the author, October 15, 2017.

12. Anonymous (college student, English major), in personal communication with the author, October 15, 2017.

13. Mata, Christine Anne S. (college student, English major), in personal communication with the author, October 15, 2017.

Kritika Kultura 35 (2020): 150-153

(C) Ateneo de Manila University

<http://journals.ateneo.edu/ojs/kk/> 
14. Apuya, Sidney (college student, English major), in personal communication with the author, October 15, 2017.

15. Anonymous (English teacher no. 5), in personal communication with the author, October 13, 2017.

16. Soledad, Neil Francis (college student, English major), in personal communication with the author, October 15, 2017.

17. Anonymous (English teacher 1), in personal communication with the author, October 13, 2017.

18. Anonymous (English teacher 5), in personal communication with the author, October 13, 2017.

19. Mengullo, Florenza Mae (college student, English major), in personal communication with the author, October 15, 2017.

20. Cañanes, Mervin Clyde (college student, English major), in personal communication with the author, October 15, 2017.

21. Mengullo, Florenza Mae (college student, English major), in personal communication with the author, October 15, 2017.

22. Badango, Joan (college student, English major), in personal communication with the author, October 15, 2017.

23. Anonymous (English teacher 1), in personal communication with the author, October 13, 2017.

24. Anonymous (English teacher 3), in communication with the author, October 13, 2017.

25. Masaplod, Troy Roger, (college student, English major), in personal communication with the author, October 10, 20017.

26. Anonymous (English teacher 2), in personal communication with the author, October 13, 2017.

Kritika Kultura 35 (2020): 151-153

(c) Ateneo de Manila University

<http://journals.ateneo.edu/ojs/kk/> 


\section{Works Cited}

Alunan, Merlie M. "Latitudes of Intimacy: New Waray Writing and National Literature (for the Bienvenido Lumbera Festschrift)." Huruhimangraw. 8 Nov. 2014. Accessed 26 Nov. 2016.

Alburo, Erlinda. "Return to the Native." The Mindanao Forum, vol. XXI, no. 1, June 20o8, pp. 66-72.

Alunan, Merlie M., and Evelina M. Acebedo, et. al., editors. Mga Siday han DYVL. Committee on Literature National Commission on Culture and the Arts, DYVL Action Radio, University Press, Tacloban College Writing Workshop, 2005.

Aniceto, Ben. Stay Tuned: The Golden Years of Philippine Radio: A Historical Perspective of Philippine Radio - Its Beginnings, Its Golden Years and Its Suppression in September, 1972. Atlas Publishing, 2007.

Bagulaya, Jose Duke S. “The Form and Ideology of Leyte's Popular Radio Siday: A Critique." Plaridel, vol. 3, no. 1, Feb. 2006, pp. 87-122.

Beck, Alan. "The Death of Radio? An Essay in Radio-Philosophy for the Digital Age." Sound Journal, 2002. www.savoyhill.co.uk/deathofradio/index.html. Accessed 1o Nov. 2016.

Enriquez, Elizabeth L. Appropriation of Colonial Broadcasting: A History of Early Radio in the Philippines, 1922-1946. U of the Philippines P, 2008.

Finnegan, Ruth. Oral Poetry: Its Nature, Significance and Social Context. Cambridge UP, 1977.

Gioia, Dana. "Disappearing Ink: Poetry at the End of Print Culture." The Hudson Review, vol. 56, no. 1, 2003, pp. 21-49.

Jocson, Korina M. "Literacy Learning, Empowerment and Poetry." Counterpoints, vol. 304, 2008, pp. 15-40.

Kaplan, Milton A. "American Speech in Radio Poetry." American Speech, vol. 19, no. 1, Feb. 1944a, pp. 28-32.

--. "Radio and Poetry". Poetry, vol. 64, no. 5, Aug. 1944, pp. 270-279.

Kennedy, X. J., and Dana Gioia. An Introduction to Poetry. 12th ed., Pearson Longman, 2007.

Lent, John A. "Philippine Radio: History and Problems." Asian Studies: Journal of Critical Perspectives on Asia, vol. 6, no. 1, 1968, pp. 37-52.

McHugh, Siobhan. "The Affective Power of Sound: Oral History on Radio." Oral History Review, vol. 39, no. 2, 2012, pp. 187-206.

Ong, Walter J. Orality and Literacy: The Technologizing of the Word. Routledge, 2001.

Orfanella, Lou. "Radio: The Intimate Medium." The English Journal, vol. 87, no. 1, 1998, pp. $53-55$.

Oyzon, Voltaire Q., Firie Jill T. Ramos, and Michael Carlo C. Villas. "Acoustic Properties of Waray Vowels: Towards a New Waray Orthography.” Pambasang Summit sa Wika, 29-3o Apr. 2011, U of the Philippines Baguio, Baguio City.www.academia.edu/29477634/Acoustic_Properties_of_Waray_ 
Vowels_Towards_A_New_Waray_Orthography_Background_and_Rationale. Accessed 23 Aug. 2017.

Ratcliffe, Stephen. Listening to Reading. State U of New York, 2000.

Schaffer, Murray R. Our Sonic Environment and the Soundscape: The Tuning of the World. Destiny Books, 1997.

Shouse, Eric. "Feeling, Emotion, Affect." Media and Culture Journal, vol. 8, no. 6, 2005. journal.media-culture.org.au/o512/03-shouse.php>. Accessed 15 Nov. 2016.

Spaulding, John. "Poetry and the Media: The Decline of Popular Poetry." The Journal of Popular Culture, vol. 33, no. 2, Fall 1999, pp. 147-153. onlinelibrary.wiley.com/ doi/10.1111/j.0022-3840.1999.3302_147.x/abstract. Accessed 16 Nov. 2016.

Street, Sean. The Poetry of Radio: The Colour of Sound. Routledge, 2012.

Tuazon, Ramon R. "Radio as a Way of Life." National Commission for Culture and the Arts. ncca.gov.ph/about-ncca-3/subcommissions/subcommission-on-culturaldisseminationscd/communication/radio-as-a-way-of-life/. Accessed 1o Dec. 2016.

Vilches, Ma. Luz. "A Preliminary Survey of Waray Poetry." Kandabao: Essays on Waray Language, Literature, and Culture, edited by Gregorio C. Luangco, Divine Word U Publications, 1982, pp. 62-64.

--. A Study of the Waray Lyric Poetry of Iluminado Lucente. MA Thesis. Ateneo de Manila University, 1976. 